\title{
Relationship Between SUV $\max$ and Ki-67 Expression in Breast Cancer
}

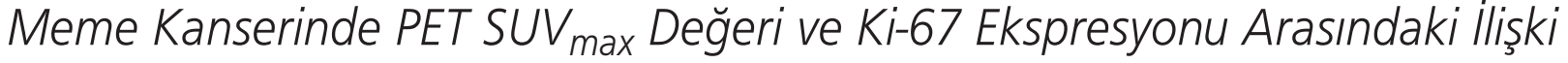 \\ ๑ Meriç Emre Bostancı, ๑ Zekiye Hasbek* \\ Cumhuriyet University Faculty of Medicine, Department of Surgical Oncology, Sivas, Turkey \\ *Cumhuriyet University Faculty of Medicine, Department of Nuclear Medicine, Sivas, Turkey
}

\section{Abstract}

\begin{abstract}
Aim: Breast cancer is the most common type of cancer in women. The Ki-67 antigen is a factor used for subgrouping of luminal breast cancer into A and B subtypes. 18F-fluorodeoxyglucose positron emission tomography/computed tomography (18F-FDG PET/CT) is an effective imaging method in the evaluation of patients with locally advanced breast cancer. The aim of this study was to evaluate the relationship between maximum standardized uptake value $\left(\mathrm{SUV}_{\max }\right)$ and $\mathrm{Ki}-67$ expression levels in primary breast cancer.
\end{abstract}

Methods: Fifty-one female patients (43-83 years, mean: 64.7 \pm 9.7 years) diagnosed and operated for breast cancer were included in this retrospective study. ${ }^{18 F-F D G ~ P E T / C T ~ w a s ~ p e r f o r m e d ~ f o r ~}$ each patient with the purpose of staging. Ki-67 expression levels obtained from pathology data were divided into three groups as $<15 \%, 15-29 \%$, and $>30 \%$, and SUV max $_{\text {values obtained from }}$ 18F-FDG PET/CT were compared between the groups.

Results: A analysis of Ki-67 expression levels and SUV $\mathrm{max}_{\max }$ of the primary tumor revealed a moderate and significant correlation between $\mathrm{SUV}_{\max }$ and $\mathrm{Ki}-67$ expression levels. Also, a statistically significant relationship was found between $S V_{\max }$ of the primary tumor in the breast and estrogen receptor positivity and progesterone receptor positivity. Although not statistically significant, the mean SUV $\mathrm{max}_{\text {in }}$ in triple-positive patients was high.

Conclusion: The correlation between SUV $\mathrm{Smax}_{\text {ma }}$ ai-67 expression levels was found to be moderate and statistically significant. However, further studies with more homogeneous groups and larger sample size are needed.

Keywords: Breast cancer, Ki-67, SUV $\max$
Amaç: Meme kanseri kadınlarda en sık görülen kanser türüdür. Ki67 meme kanserinin Luminal A ve Luminal B alt gruplandırılması için kullanılan bir faktördür. 18F-florodeoksiglukoz, Pozitron Emisyon Tomografi/Bilgisayarlı Tomografi (18F-FDG PET/CT) ise hastalığın evreleme, yeniden evreleme ve tedavi cevabının değerlendirilmesinde rutinde sıklıkla kullanılan önemli bir görüntüleme yöntemidir. Bizim çalışmamızın amacı, primer meme kanserindeki standardize edilmiş maksimum tutulum değeri $\left(S U V_{\text {max }}\right)$ değerleri ile Ki-67 ekspresyon düzeyleri arasındaki ilişkiyi değerlendirmektir.

Yöntemler: Retrospektif olarak gerçekleştirilen bu çalışmada primer meme kanseri tanısı konan ve opere edilen hastalardan evreleme amaçılı 18F-FDG PET/CT yapılan 51 kadın hasta (4383 yaş, ortalama: $64,7 \pm 9,7$ yaş) çalışmaya dahil edildi. Patoloji verilerinden elde edilen Ki-67 ekspresyon düzeyleri <\%15; \%1529 ve >\%30 olmak üzere üç gruba ayrıldı ve grupların ${ }^{18 F-F D G}$ PET/CT'den elde edilen SUV $V_{\text {max }}$ değerleri karşılaştıııldı.

Bulgular: Ki-67 ekspresyon düzeyleri ile primer meme malignitelerine ait SUV $V_{\max }$ değeri karşılaştırıldığında, SUV $V_{\max }$ ve Ki-67 ekspresyon düzeyleri arasında istatistiksel olarak anlamlı, orta kuvvette bir korelasyon saptandı. Ek olarak memedeki primer tümöre ait SUV $V_{\max }$ değeri ile östrojen reseptör pozitifliği ve progesteron reseptör pozitifliği arasında istatistiksel olarak anlamlı bir ilişki vardı. Triple-pozitif olanlarda SUV $V_{\max }$ değerleri ortalaması da yüksek olmakla birlikte istatistiksel olarak anlamlı bulunmadı.

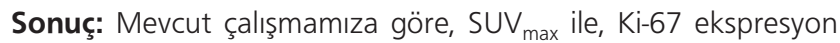
düzeyi arasındaki korelasyon orta düzeyde ve istatistiksel olarak anlamlıdır. Ancak daha homojen gruplar ve daha çok hasta sayısı ile yapılacak ileri çalışmalara ihtiyaç vardır.

Anahtar Sözcükler: Meme kanseri, Ki-67, SUV $\max$
Address for Correspondence/Yazışma Adresi: Meriç Emre Bostancı, Cumhuriyet University Faculty of Medicine, Department of Surgical Oncology, Sivas, Turkey E-mail: drmericemrebostanci@gmail.com ORCID: orcid.org/0000-0002-0429-9834 Received/Geliş Tarihi: 15 January 2020 Accepted/Kabul Tarihi: 30 June 2020
${ }^{\circ}$ Copyright 2020 by The Medical Bulletin of istanbul Haseki Training and Research Hospital The Medical Bulletin of Haseki published by Galenos Yayınevi. ${ }^{8}$ Telif Hakkı 2020 istanbul Haseki Eğitim ve Araştırma Hastanesi Haseki Tıp Bülteni, Galenos Yayınevi tarafından yayınlanmıştır. 


\section{Introduction}

Breast cancer, which is the most common type of cancer in women, is seen at a rate of $11.6 \%$ when all cancers are considered (1). The Ki-67 antigen, a protein encoded by the MKI67 gene, is a factor used for the subgrouping of breast cancer as luminal A and luminal B (2). As in many cancers, it has prognostic significance in breast cancer, and high Ki-67 expression levels are associated with poor prognosis (3). Keam et al. (4) reported that triple-negative breast cancer patients with high Ki-67 expression levels had pathological complete response to neo-adjuvant therapy. However, these patients have earlier recurrence potential, and overall survival is shorter than in patients with low Ki-67 expression levels.

Using state-of-the-art imaging methods in breast cancer for early detection and appropriate treatment strategies play a key role in improving survival rates. Magnetic resonance imaging of the breast has an important role in the detection of breast cancer, whereas ${ }^{18} \mathrm{~F}$-fluorodeoxyglucose positron emission tomography/computed tomography $\left({ }^{18} \mathrm{~F}-\mathrm{FDG} \mathrm{PET} / \mathrm{CT}\right)$ is a valuable imaging method that is frequently used in routine assessment of disease, treatment response, staging, and restaging. Maximum standardized uptake value $\left(S_{U V} V_{\text {max }}\right)$, which is a numerical value indicating the uptake of FDG by the malignant tissue during PET/ $\mathrm{CT}$ imaging, has a prognostic, predictive value in breast cancers as in many tumors (5).

The purpose of our study was to evaluate the relationship between SUV $V_{\text {max }}$ and Ki-67 expression levels in primary breast cancer.

\section{Methods}

In this retrospective study, we included 51 female patients with the mean age of $64.7 \pm 9.7$ years (range: 43-83 years) diagnosed with breast cancer and operated between January 6, 2017 and July 1, 2019 in Cumhuriyet University Training and Research Hospital Surgical Oncology Clinic. ${ }^{18}$ F-FDG PET/CT was performed in all patients. The data of the patients were obtained from patient files, electronic file systems, data archive system of the pathology department, and data archive system of the nuclear medicine department. SUV ${ }_{\text {max }}$ value in the primary breast tumor and metastatic axillary lymph nodes, if any, were noted from the original PET/CT reports. The histologic type of breast cancer, percentages of Ki-67positive cells (Ki-67 index), and estrogen receptor (ER), and progesterone receptor (PR) status were noted from pathology reports of biopsies taken from the patients individually. The patients were divided into three groups according to their Ki-67 expression levels; <15\%; 15-29\% and $>30 \%$.

\section{PET/CT Imaging Acquisition Analysis}

Positron emission tomography was performed using a combined PET/CT scanner (Discovery600 PET/CT GE Medical Systems, USA). Each patient fasted for at least 6 $\mathrm{h}$ before imaging. After ensuring that blood glucose was $<180 \mathrm{mg} / \mathrm{dL}$, approximately $0.14 \mathrm{mCi} / \mathrm{kg}{ }^{18} \mathrm{~F}-\mathrm{FDG}$ were administered i.v. $1 \mathrm{~h}$ before image acquisition. Attenuation correction of PET images with the CT data was performed. CT scan was performed firstly. Right after CT acquisition, a standard PET imaging protocol was taken from the cranium to the mid-thigh with an acquisition time of $3 \mathrm{~min} / \mathrm{bed}$ in 3-dimensional mode. All PET studies were acquired in 3-D mode. CT images were acquired with $70 \mathrm{~mA}, 120 \mathrm{kV}$, axial slice thickness of $2.5 \mathrm{~mm}$. CT and PET images were matched and fused into transaxial, coronal, and sagittal images. The data were transferred via the Digital Imaging and Communications in Medicine protocol to a processing Workstation (AW Volume Share5 GE Medical Systems S.C.S, France). Later, visual and semi-quantitative analyses were performed, respectively.

\section{Statistical Analysis}

Statistical analysis was performed using the SPSS software, version 24.0. A $p$ value less than 0.05 was considered statistically significant. Correlation analysis was performed to determine the relationship between $\mathrm{Ki}$ 67 expression levels and SUV $V_{\text {max }}$. Following the grouping according to Ki-67 expression levels, the chi-square test was used to analyze estrogen and PRs and triple-negative/ positive patients.

\section{Results}

Of the 51 patients included in the study, 42 (82.4\%) had invasive ductal carcinoma, two (3.9\%) micropapillary carcinoma, two (3.9\%) apocrine carcinoma, two (3.9\%) mucinous carcinoma, one (2\%) cribriform, one (2\%) invasive papillary carcinoma and one (2\%) ductal carcinoma in situ. Median SUV max $_{\text {in }}$ primary breast malignancies was 4 (range: 1-23). The analysis of Ki-67 expression levels and SUV $V_{\max }$ of the primary tumor revealed a moderate and significant correlation between SUV $V_{\max }$ and Ki-67 expression levels (correlation coefficient: 0.68; $p<0.05$ ). It was found that in patients with axillary involvement detected by PET, axillary SUV max $_{\text {ax }}$ levels increased with the increase of Ki-67 expression levels (Table 1; Figure 1), but it was not statistically significant. ER and PR positivity/ negativity was tested in 49 patients. A statistically significant relationship was found between SUV $\mathrm{max}_{\text {ax }}$ of the primary tumor in the breast and ER and PR positivity ( $p=0.007$ and $p=0.005$, respectively) (Table 2 ). Besides, there was a statistically significant relationship between Ki-67 expression levels and ER and PR positivity $(p=0.002$ and $p=0.015$, respectively). Ki-67 expression levels were 


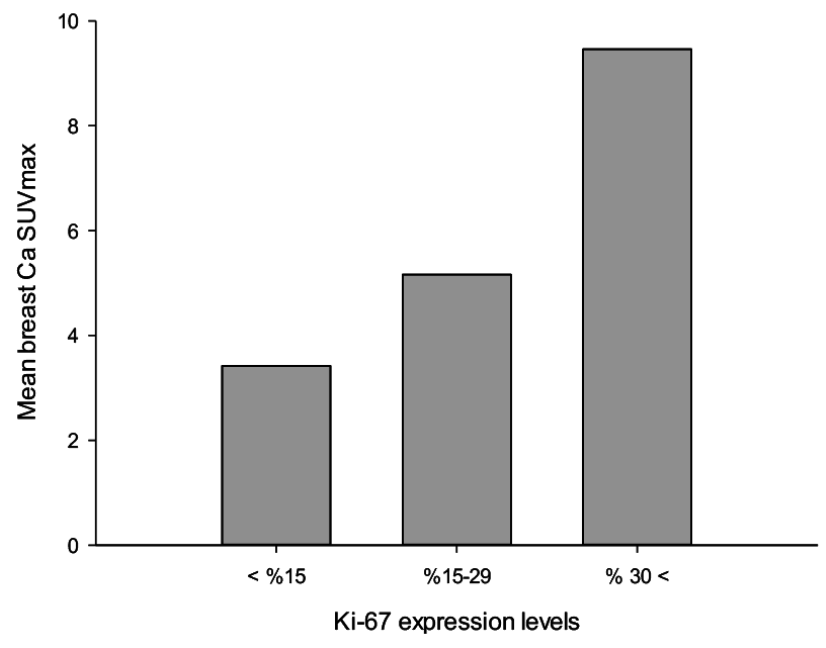

Figure 1. The relationship between $\mathrm{Ki}-67$ expression levels and SUV $_{\text {max }}$ of primary breast tumor

SUV $V_{\text {max }}$ : Maximum standardized uptake value
$<15 \%$ in triple-negative patients, whereas Ki-67 expression levels were higher in triple-positive patients $(p=0.086)$

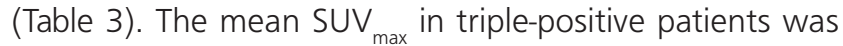
also high, but it was not statistically significant $(p=0.072)$.

\section{Discussion}

Breast cancer is the most common cancer in women in Turkey (6). Disease-free survival rates are high in patients diagnosed at an early stage (7). ${ }^{18} \mathrm{~F}-\mathrm{FDG}$ PET/CT is a common imaging modality used in the evaluation of many types of cancer, including breast cancer. In their study, Kitajima et al. (8) reported that high $\operatorname{SUV}_{\max }(\geq 6.20)$ and high Ki67 expression levels were associated with recurrence,

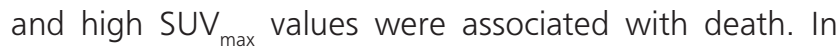
their meta-analysis, Surov et al. (9) found a moderate correlation between SUV max $_{\text {and }}$ Ki-67 expression in breast

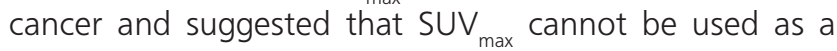
surrogate marker for tumor proliferation. On the other hand, in their study including 140 breast cancer cases, of which 136 were women, Ekmekcioglu et al. (10) reported

\begin{tabular}{|c|c|c|c|c|c|c|c|}
\hline & & & Minimum & Maximum & Mean & SD & $p$ \\
\hline \multirow{3}{*}{ Primary breast tumor SUV $_{\max }$} & \multirow{3}{*}{ Ki-67 } & $<15 \%$ & 1.20 & 5.90 & 3.42 & 1.13 & \multirow{3}{*}{0.001} \\
\hline & & $15-29 \%$ & 1.30 & 13.70 & 5.12 & 3.88 & \\
\hline & & $>30 \%$ & 1.70 & 23.40 & 9.44 & 6.12 & \\
\hline \multirow{3}{*}{ Axillary lymph node SUV max $_{\text {max }}$} & \multirow{3}{*}{$\mathrm{Ki}-67$} & $<15 \%$ & 1.40 & 4.40 & 2.94 & 1.04 & \multirow{3}{*}{0.136} \\
\hline & & $15-29 \%$ & 1.20 & 9.60 & 4.49 & 3.94 & \\
\hline & & $>30 \%$ & 1.30 & 16.80 & 6.52 & 4.62 & \\
\hline
\end{tabular}

\begin{tabular}{|c|c|c|c|c|c|c|c|}
\hline & & & Minimum & Maximum & Mean & SD & $p$ \\
\hline \multirow{6}{*}{$\begin{array}{l}\text { Primary breast tumor } \\
\text { SUV }_{\max }\end{array}$} & \multirow[b]{2}{*}{ ER } & Positive & 1.20 & 15.9 & 4.88 & 3.53 & \multirow[b]{2}{*}{0.007} \\
\hline & & Negative & 2.30 & 23.4 & 10.22 & 6.82 & \\
\hline & \multirow{2}{*}{ PR } & Positive & 1.20 & 15.9 & 4.75 & 3.77 & \multirow{2}{*}{0.005} \\
\hline & & Negative & 2.30 & 23.40 & 8.65 & 6.12 & \\
\hline & \multirow{2}{*}{ c-erbB-2 } & Positive & 1.30 & 18.30 & 5.65 & 4.09 & \multirow{2}{*}{0.974} \\
\hline & & Negative & 1.20 & 23.4 & 7.34 & 6.77 & \\
\hline
\end{tabular}

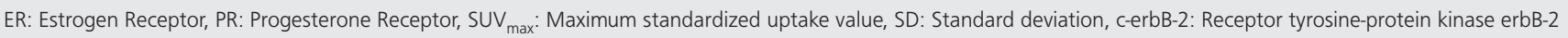

Table 3. The relationship between $\mathrm{Ki}-67$ expression and triple-negative/positive breast tumor $(\mathrm{p}=0.086)$

\begin{tabular}{|c|c|c|c|c|}
\hline & \multicolumn{3}{|c|}{ Ki- 67 expression levels } & $\mathbf{p}$ \\
\hline & $<15 \%$ & $15-29 \%$ & $>30 \%$ & \multirow{5}{*}{0.086} \\
\hline & n (\%) & n (\%) & n (\%) & \\
\hline Triple-negative & $17(40.5)$ & $17(40.5)$ & $8(19)$ & \\
\hline Triple-positive & $2(28.6)$ & $1(14.3)$ & $4(57.1)$ & \\
\hline Total & 19 (38.8) & $18(36.7)$ & $12(24.5)$ & \\
\hline
\end{tabular}


a high degree of correlation between SUV $V_{\max }$ of the primary tumor and tumor/background $S U V_{\text {max }}$ rates and high Ki-67 expression levels. In the same study, SUV max $_{\text {mas }}$ found to be significantly associated with histological type and grade, pleomorphism, number of mitoses, lymphatic invasion, necrosis, oestrogen negativity, high Ki-67 level, axillary lymph node involvement and triple negativity, and it was reported that ${ }^{18} \mathrm{~F}-\mathrm{FDG}$ uptake might be a prognostic indicator of tumor's biological behavior. Similarly, Abubakar et al. (11) found that high SUV ${ }_{\text {max }}$ values were associated with high Ki-67 as well as high grade, triple-negative status, and axillary lymph node involvement. In our study, we showed that high $\mathrm{Ki}-67$ expression levels were associated with high SUV ${ }_{\text {max }}$ values in the primary tumor $(p=0.001)$. The mean SUV max $_{\text {max }}$ was 9.46 in patients with a Ki-67 index of $>30 \%$. These results were in accordance with studies by Ekmekcioglu et al. (10) and Abubakar et al. (11). It is known that Ki-67 levels are higher in triple-negative tumors and associated with more invasive and poorer prognosis (12). According to the data of our study, unlike the literature, patients with triple-positive tumors were found to have higher Ki-67 levels, but these data were not statistically significant. However, SUV ${ }_{\text {max }}$ levels were significantly higher in ER and PR negative patients than in positive ones (Table 2). Recent publications indicated that $\mathrm{PET} / \mathrm{CT}$ was vital in axillary lymph node staging. According to some studies, although the sensitivity of PET/CT for the detection of axillary lymph nodes in patients with breast cancer is quite high, its sensitivity is low $(13,14)$. Orsaria et al. (15) found that sensitivity, specificity, positive, and negative predictive values of ${ }^{18}$ F-FDG PET/CT were high for axillary lymph node staging. In the same study, it was found that high SUV in both lymph nodes and primary tumor was significantly correlated with high Ki-67 expression levels. Although Chung et al. (16) found no correlation between SUV $V_{\max }$ of axillary lymph node and Ki-67 expression levels, they reported that axillary lymph node examination should be performed in patients with a SUV greater than 2.3; by adopting a SUV threshold of 2.3, the sensitivity, specificity and positive predictive value of FDG-PET was 60\%, 100\% and $100 \%$, respectively. In our study, we could not find a relationship between Ki-67 expression levels and SUV max $_{\text {max }}$ levels in the axillary lymph nodes.

\section{Conclusion}

According to our study, the correlation between SUV and Ki-67 expression levels was found to be moderate and significant. However, further studies with more homogeneous groups and larger sample size are needed.

\section{Authorship Contributions}

Concept: M.E.B., Z.H. Design: M.E.B., Z.H. Data Collection or Processing: M.E.B., Z.H. Analysis or
Interpretation: M.E.B., Z.H. Literature Search: M.E.B., Z.H. Writing: M.E.B.

Conflict of Interest: No conflict of interest was declared by the authors.

Financial Disclosure: The authors declared that this study received no financial support.

\section{References}

1. https://gco.iarc.fr/today/online-analysis-population_group_ globocan

2. Goldhirsch A, Winer EP, Coates AS, et al. Personalizing the treatment of women with early breast cancer: highlights of the St Gallen International Expert Consensus on the Primary Therapy of Early Breast Cancer 2013. Ann Oncol 2013;24:2206-23.

3. Wu Q, Ma G, Deng $Y$, et al. Prognostic Value of Ki-67 in Patients With Resected Triple-Negative Breast Cancer: A Meta-Analysis. Front Oncol 2019;9:1068.

4. Keam B, Im SA, Lee KH, et al. Ki-67 can be used for further classification of triple-negative breast cancer into two subtypes with different response and prognosis. Breast Cancer Res 2011;13:22.

5. Ozkan EE, Sengul SS, Erdogan M, Gurdal O, Eroglu HE. 18F-fluorodeoxyglucose PET/computed tomography in locoregional staging and assessment of biological and clinical aggressiveness of breast cancer subtypes. Nucl Med Commun 2019;40:1043-50.

6. Özmen V. Breast Cancer in Turkey. Turkiye Klinikleri J Gen Surg-Special Topics 2013;6:1-6. http://www.turkiyeklinikleri. com/article/en-turkiyede-meme-kanseri-66538.html

7. Gray E, Marti J, Wyatt JC, Brewster DH, Hall PS; SATURNE advisory group. Chemotherapy effectiveness in trialunderrepresented groups with early breast cancer: A retrospective cohort study. PLoS Med 2019;31;16:e1003006.

8. Kitajima K, Yamano $T$, Miyoshi $Y$, Katsuura $T$, Enoki $T$, Yamakado K. Prognostic value of 18F-FDG PET/CT prior to breast cancer treatment. Comparison with magnetic resonance spectroscopy and diffusion weighted imaging. Hell J Nucl Med 2019;22:25-35.

9. Surov A, Meyer HJ, Wienke A. Associations Between PET Parameters and Expression of Ki-67 in Breast Cancer. Transl Oncol 2019;12:375-80.

10. Ekmekcioglu O, Aliyev A, Yilmaz S, et al. Correlation of 18F-fluorodeoxyglucose uptake with histopathological prognostic factors in breast carcinoma. Nucl Med Commun 2013;34:1055-67.

11. Abubakar ZA, Akepati NKR, Bikkina P. Correlation of Maximum Standardized Uptake Values in 18F-Fluorodeoxyglucose Positron Emission Tomography-computed Tomography Scan with Immunohistochemistry and Other Prognostic Factors in Breast Cancer. Indian J Nucl Med 2019;34:10-3. 
12. Ege Aktas G, Taştekin E, Sarikaya A. Assessment of biological and clinical aggressiveness of invasive ductal breast cancer using baseline 18F-FDG PET/CT-derived volumetric parameters. Nucl Med Commun 2018;39:83-93.

13. Ueda S, Tsuda $H$, Asakawa $H$, et al. Utility of 18F-fluorodeoxyglucose emission tomography/computed tomography fusion imaging (18F-FDG PET/CT) in combination with ultrasonography for axillary staging in primary breast cancer. BMC Cancer 2008;8:165.

14. Taira T, Ohsumi S, Takabatake $D$, et al. Determination of indication for sentinel lymph node biopsy in clinical node-negative breast cancer using preoperative
18F-fluorodeoxyglucose positron emission tomography/ computed tomography fusion imaging. Jpn J Clin Oncol 2009;39:16-21.

15. Orsaria P, Chiaravalloti A, Caredda E, et al. Evaluation of the Usefulness of FDG-PET/CT for Nodal Staging of Breast Cancer. Anticancer Res 2018;38:6639-52.

16. Chung A, Liou D, Karlan S, et al. Preoperative FDG-PET for axillary metastases in patients with breast cancer. Arch Surg 2006;141:788-9. 